\section{CENTENARY OF ZOOLOGICAL TEACHING IN TRINITY COLLEGE, DUBLIN*}

\author{
BY Prof. J. BRONTË GATENBY
}

$\mathrm{I}^{\mathrm{N}}$ April one hundred years ago, the Board of Trinity College, Dublin, appointed Robert Ball as director of the Museum, with rooms and facilities for delivering lectures "illustrative of its contents and uses". The study of natural history in the University of Dublin began much earlier with the work of William and Thomas Molyneux, grandsons of the Englishman, Sir Thomas Molyneux, Chancellor of the Exchequer in Ireland in 1558. It was William Molyneux who, in 1684, demonstrated the flow of the blood in the newt, by means of the microscope. Whitley Stokes, father of the great Sir William Stokes, the physician, was appointed professor of natural history and curator of the Museum in 1815. His lectures dealt with "Volcanic Theory and Igneous Origin of Rocks, different portions of Zoology, Mineralogy and a Course in Mining and Metallurgy, and with the Natural Resources of Ireland". In 1791, Whitley Stokes was put on trial for his alleged implication in the United Irishmen Movement. He suffered much for his political opinions.

After the appointment of Robert-Ball, the study of zoology was not pursued vigorously because his lectures did not have the status of a university subject. Ball, who was a Civil servant in the Chief Secretary's office, was retired on pension by the Government in $\mathbf{1 8 5 2}$ on the ground that he "devoted much attention to scientific pursuits, and it was not expedient that public servants should be thus occupied". Ball died in 1857, and in the same year, after his death, the Rev. Samuel Haughton, F.R.S., later professor of geology, announced that the Board of Trinity College had promoted the study of zoology to a recognized university subject. Haughton took an active interest in the development of the School of Physic at Trinity College, and was responsible for bringing in first-class men from outside, such as Alexander Macalister (later professor of anatomy at Cambridge) and Daniel Cunningham (of Edinburgh), whose two sons, Admiral Sir Andrew Cunningham and General Sir Alan Cunningham, have had remarkable careers in recent times. After Robert Ball, the human anatomist Robert Harrison was appointed the first lecturer in zoology, a position he occupied for two years. Afterwards, Edward Percival Wright was appointed lecturer, and then in 1868 became the first professor of zoology. Wright transferred to the Botany School of Trinity College in 1869, and Alexander Macalister was brought in from the College of Surgeons of Ireland as professor of zoology (and comparative anatomy) in 1870. Later, Macalister became professor of human anatomy and chirurgery in Trinity College; he went to Cambridge in 1883. $\mathrm{He}$ was succeeded by William Henry Mackintosh as professor of zoology in 1879, who held the chair for fortytwo years. He was at the same time registrar of the School of Physic, a position which needed considerable work; his interest in theology and missionary teaching also made inroads in his time, so that he did not publish any original work in the middle and later periods of his life.

It is of interest to zoologists to notice that George

* From an address delivered to the Dublin University Biologica Association on May 22 .
James Allman, the authority on Hydrozoa, was appointed professor of botany in Trinity College in 1844, and that the foundations of his exact knowledge of various groups of Cœlenterata were laid in Dublin. Allman was professor of botany in Dublin for twelve years, going to the chair of natural history in Edinburgh in 1856. James Allman was born at Bandon, Co. Cork, in 1812, and at first studied for the Irish Bar. Later he abandoned law and entered the College of Surgeons. He obtained what training he had in science, partly at the Irish College of Surgeons and partly in various private medical schools which then flourished in Great Britain and Ireland. Allman was attracted to the study of the Colenterata, after hearing a paper on a "large and beautiful collection of zoophytes" made by a Mr. A. H. Hassell, a Düblin amateur zoologist.

Another great College of Surgeons graduate who did much for the Trinity College School was Alexander Macalister. His father had been brought to Dublin in 1830, as secretary of the Sunday School Society of Ireland. When a small boy, Alexander Macalister was befriended by the curator of the Glasnevin Botanical Gardens, and on his advice, sent to the College of Surgeons at the age of fourteen, becoming a qualified medical man three years later. In view of the fact that Macalister's schooling was poor, it is astonishing that Dr. E. Barclay-Smith (J. Anat., 54 ; 1919-20) was able to write of him, "he was an able mathematician and familiar with many languages both living and dead. In Archæology, Zoology, Egyptology, Theology, Biblical History . . . he was an inexhaustible mine of knowledge". Macalister was for thirty-six years professor of anatomy at Cambridge. Macalister was born in 1844, the same year that George James Allman and Robert Ball became members of the staff of Trinity College, Dublin.

\section{FORTHCOMING EVENTS}

(Meeting marked with an asterisk * is open to the public) Saturday, June 10

INSTITUTE OF PHYSICS (EIECTRONICS GROUP) (at the Royal Society, Burlington House, Piccadilly, London, W.1), at 2.30 p.m.--Discussion on "Some Aspects of High Vacuum Technique, viz., High Vacuum Gauges and Glass Manipulation" (to be opened by Dr. M. Pirani and Dr. B. P. Dudding).

Monday, June 12

RoYal Geographical Socrety (at Kensington Gore, London, S.W.7), at 5 p.m.-Mr. Gordon Manley: "Topographical Features and the Climate of Britain".

Tuesday, June 13

ROYAL A vTHROPOLOGICAL INSTITUTE (at 21 Bedford Square, LonROYAL ANTHROPOLOGICAL INSTITUTE (at 21 Bedford Square, London, W.C.1), at 1.30 p.m.-Dr. Elise
tions on the Prehistory of Egypt".

QUEKaTT MrcRoscopicax CLUB (at the Royal Society, Burlington House, Piccadilly, London, W.1), at 7 p.m.-Mr. C. H. Caffyn: "Rocks and their Structure".

\section{Wednesday, June 14}

INSTITUTION OF ELECTRICAI ENGINEERS (MEASUREMENTS SECTION) (at Savoy Place, Victoria Embankment, London, W.C.2), at 3.30 p.m. -Discussion on "The Consumer's Supply Control Unit of the Future and its Effect on the Design of the Electricity Meter".

Thursday, June 15

British Psychological Socrety (Industrial Section) (at the ( London, W.C.2), at 1 p.m.-Mr. H. G. Maule: "Some Áspects of London, W.C.2), at 1 p.m.-Mr.;

LONDON MATHEMATICAL Societr (at the Royal Astronomical Society, Burlington House, Piccadilly, London, W.1), at 3 p.m.Dr. H 'The Mathematical and Historical Back ground of Hilbert's Theory of the Continuous Spectrum".

Chadwick Public Leoture (at the Chelsea Physic Garden, Swan Walk, Chelsea, London, S.W.3), at 4 p.m.-Dr. B. Barnes: "Vegetation and Human Well-Being"."

Saturday, June 17

Brochemical Societr (in the Physiology Department, University College, Dundee), at 2 p.m. 